for strength; and in the section, fig. 3, the metal was distributed as far as possible from the centre, thereby securing the full advantages obtained by the depth.

Mr. Slate conceived it a matter of the highest importance to diminish dead weight; and that great improvements had yet to be effected in that particular; certainly, if they had now 5 tons of dead weight where they had formerly 34 tons, they had not much improved; for they had thereby increased the cost of traction one-half. He did not know of any instance where there was so large a proportion of dead weight in any kind of machinery as there was in railway rolling stock; and the dividends on railway property must be diminished by it. It was surprising that, on a road possessing such perfection and advantages, they should have such an enormous proportion of dead weight; in an abstract sense, it rendered the new,railways less perfect than the old roads, where the proportion of dead weight was so much less.

Mr. Wright thought it ought to be observed, that railway-carriages had been much increased in their size, to suit the convenience and comfort of travelers. Originally, they were 15 feet long, 6 feet 6 inches wide, and 4 feet 9 inches high; but now they were from 18 to 20 feet in length, 7 feet wide, and 5 feet 6 inches high. The increase in size was of course one element in the increase of weight. Originally, in the case of the axle-journals, they were $4 \frac{1}{2}$ by $2_{1}^{3}$ inches; but they had soon increased to 5 by $2 \frac{5}{8}$ inches, and were now much larger; also, the wheels were originally 17 cwt.; but now they weighed from $25 \mathrm{cwt}$. to $27 \mathrm{cwt}$. These had to do the same business; the number of passengers were not increased, but the vehicles to carry them were heavier.

Mr. Henson was of opinion that, before long, the dead weight would be reduced one-third, while the' weight carried was increased one-third; and that the cost would be also diminished. He was engaged in the consideration of the subject, and would be glad to bring the results before the Institution at a future meeting.-Proc. Inst. Mech. Eng.

On the History and Construction of the Britannia Bridge. By Mr. Geo.

$$
\text { Grove, Secretary. }
$$

It was originally intended that the Chester and Holyhead Railway should cross the Menai Straits by Telford's well known suspension bridge; but this plan was abandoned on account of engineering difficulties; and the site occupied by the present bridge was fixed on. It takes its name from the Britannia Rock, lying in mid-channel; on which its centre pier is founded. At this place, $\mathrm{Mr}$. R. Stephenson proposed to build a bridge of two cast-iron arches, each of 350 feet span and 100 feet in height, which were to be erected without the use of centres, by continued additions to the spandrils, each piece being connected to its fellow on the opposite side of the pier by tie-rods. An end was put to this design by the requirement of the Admiralty, that the same height should be preserved at the springing of the arch as at the crown; in other words, that its under side should be a straight line.

- From the London Journal of Arts and Sciences, for March, 1851. 
In this position of affairs, the conception of a tube occurred to $\mathrm{Mr}$. Stephenson; and to determine its shape and the details of its construction, he was empowered by the directors of the line to make a magnificent series of experiments, which were conducted at the works, and under the care of Mr. Wm. Fairbairn, at Millwall. The first series of experiments was on 34 tubes, of three different sections, round, oval, and square or rectangular, varying in length from 18 to 27 feet, and in diameter from 9 to 18 inches. 'They were, in all cases, supported at their ends, the testing weight being hung at the middle, till fracture took place. The rectangular form was found to be much the strongest: it was the only one in which failure did not take place in the upper side.

When a beam, supported at its ends, is loaded at the middle, the fibres of the top, or upper side, are compressed; while those of the bottom are stretched. When, therefore, a beam of uniform shape is broken by the failure of the top, it is eviclent that the strength of the material to resist compression is not equal to that with which it resists tension; and the reverse. The power of cast-iron to resist compression is to its power of resisting tension as 5 to 1 ; while, by these experiments, it was discovered that in wrought iron the proportion is reversed, its power to resist compression being to its power to resist tension as 9 to 11 .

The second series was on a model tube, one-sixth of the dimensions assumed for the real bridge, 75 feet long, 4 feet high, 2 feet 9 inches wide. The sides and bottom were of single plate; but the top contained six cells, or flues, running from end to end. Six experiments were made with this model, to determine the proper proportion to be kept between the material of the top and of the bottom. In the last experiment, the tube broke with 86 tons suspended-equal to 172 tons distributed over its length-the sectional area of the top being $26 \frac{1}{2}$ inches, and that of the bottom $22 \frac{1}{2}$, or as 11 to 9 very nearly.

During these experiments, the masonry of the bridge was proceeding rapidly.

The Britannia Rock is in mid-channel; and upon it is the tower called by its name, which, at its base, is 60 feet by 50 feet 5 inches. Its entire height is 221 feet 3 inches. It is not of solid masonry; but contains a centre wall, dividing it into two wells, which are arched over under the tubes at a height of 97 feet from the base. The sides are tapered, so that at the level of the bottom of the tubes it is 51 feet 4 inches by 45 feet 5 inches.

At a distance of 460 feet on each side of the Britannia Tower stand the two land towers on the Carnarvon and Anglesey shores. At their base they are 60 feet by 37 feet; and at the level of the tubes 51 feet 4 inches by 32 feet.

From the land towers to the face of the abutments, which stand still further inland, is a space of 230 feet. The abutments themselves are in all 176 feet long. Each entrance is guarded by a pair of gigantic lions, carved in limestone, from the design of Mr. Thomas. The external parts of the masonry are of "Anglesey marble:" a hard mountain-limestone, full of fossils, extremely durable, and with an appearance of great solidity. 'This stone is backed in with Runcorn red sandstone, and with brick-work in cement. 
A large number of cast iron girders were built in to the solid stonework. for the purpose of effectually distributing the pressures of the enormous weights which were carried by certain spots during the lifting of the tube. Of these, the Britannia Tower contains no less a weight than 394 tonsthe total weight in the towers and abutments being 922 tons.

The scaffolding employed was constructed on the modern plan, with whole balks of very large timber.

The dimensions of the tubes having been definitely fixed, it was determined to build the four large ones on platforms or jetties, lying aloag the high-water mark of the Carnarvon shore; then to float them to the foot of the towers; and finally raise them to their places by hydraulic power. 'The land-tubes were to be built in their places on scaffolding.

Supposing one of the large tubes to be completed, and lying ready to be floated on the platform; -it is 472 feet long,-3 feet higher at the end which is to enter the Britannia Tower than at the other, which is 27 feet. high. It has eight cells in the top, and six in the bottom; in both cases. 1 foot 9 inches high, but of different widths. The platforms, forming the upper and lower sides of the top cells, are of single thickness; and they are connected with the upright plates of the cells by two angle-irons. inatched on the opposite side of the plate by a flat strip. These junction are formed by rivets, which are inserted at a red heat, and, while hot, arc. closed up-exerting, by their contraction, a great perwer on the plates through which they pass. The riveting of the lower part of the top cells. is performed with ease before the tup platform is put on; but, to accom-. plish the riveting of the latter, it is necessary that the "holder up" (the man who keeps the rivet in its place whilst its head is being beaten up. and his boy should be inside the cells; which they are for hours together. While in this position the rivets are supplied to them through small holes, Jett for that purpose.

The plates, forming the sides, run vertically; and they are joined to. gether by double T-irons, which form a pillar of great strength at every two feet distance throughout the tribes. 'These $\mathrm{T}$-irons are bent round at right angles, and riveted to the platform of the top and bottom; and a triangular plate, called a gusset, is used to fill the corners with great effect, against the twisting strain exerled by the wind. The platforms of the bottom cells are of double thickness of plates, arranged so as to break joint; the covers (plates riveted over the joints) being, large and stsong; the whole forming, in fact, a chain to resist tension; while the top is con: structed with small covers and nicely-executed joints, so as to act as a pillar to resist compression. The sectional area of the "top" of the tube, at the Britannia Tower, is 648 , that of the "bottom," 585 square inches.

Cast iron frames, of great strength, are fitted into each end of the tubes, and into the lower set of cells, to resist the great crushing or "shearing" strain occurring at the points of support in the towers. To these frames are fitted the iron beans to which the lifting chains are subsequently a:tached, and which consist of three very strong cast-iron girders, accurately fitted, having pillars of iron jammed between them, and a strap of wrought-iron passing completely round them, so as to make them all into one solid mass.

Vol. XXI.-Thind Senres.-No. 5.-Mar, 1851. 
The tubes having been completed on the platforms, it was necessary that they should be cut away, that room might be made for the pontoons, by which the work of transport was to be done. 'Temporary stone towers were therefore built under each end, and a packing of elm planks inserted to receive the pressure of the tube. 'The platforms bad been built with an upward curve of 9 inches; and it was found that, after they were cut away, and the tube took its own bearing, the deflexion only slightly exceeded this.

'The rocky beach, beneath the tubes, was next excavated to admit the pontoons. 'These were eight in number-six of wood, 100 feet in length, 25 feet wide, and 10 fect deep; and two of iron, of the same length, but 31 feet wide, and 8 feet 9 inches deep. 'They were arranged before the tube in two groups, and wee divided by partitions, or bulkheads, into several compartments, each having a valve, that could be shut or opened by screws on deck, and by which any amount of water could be admitted to diminish or wholly destroy the buoyancy: they were also provided with pumps for removing this water, or any that might leak in. By keeping these valves open, the pontoms remained perfectly still below the tube till the time rame for lloating.

The principle on which it was determined to conduct the floating of the first tube was, that the tube should be hauled out into the flowing or rising tide, which runs in the required direction, when the velocity of the tide was such as to bring the tube to the foot of the piers just at the time of high water; the ends of the tube being brought over stone shelves, prepared at the bases of the towtrs, on which, as the tide descended, it would be left resting. Thu, the tide itself was made to do the work of transport, and no exertion rould be wanted, except for the purpose of pilotage.

The difficulties which hat to bo: guarded against were enormous. A mass of 2000 tons in weight, and of the most cumbrous awkward shape imaginable, had to be navigated in a ticleway where the current is often eight miles per hour, with the risk of a capricious wind springing up (as in every mountainous country they unexpectedly do,) which would act with fearful effect on the huge sail-surfice of the tube; this unwieldy mass had to be turned half round on its passage, and guided safely past the points of the Britannia Rock; and, lastly, there was the absolute impossibility of making any change in the arrangements as unforeseen emergencies might occur.

Two 12-inch ropes were laid down the stream from a sunk mooring, opposite the farthest tube, to two capstans on the other side of the Anglesey land-tower; and on them the tube was to travel, as a ferry-boat, on its guide-lines. They ran over the pontoons, where they passed through cable-stoppers, or contrivances by which the rope could, on occasion, be gripped so hard as to stop the motion of the whole mass. These guidelines were buoyed up by casks, attached at intervals, to protect them from the sharp rocks of the bottom. Two 8-inch lines, leading from moorings on the opposite shore to capstans on the shores and on the Britannia Rock, were to effect the last delicate operation of placing the tube in its ultimate position. 
The capstans were fully manned by 11 superintendents, 450 laborers, 65 sailors, and 12 carpenters. Each capstar had 48 men; each set of pontoons carried 105 hands; and 6 boats, with spare line, attended the tube in its outward progress. The capstans were signalled-to from the tube by holding up the distinguished letter of the capstan and a flag, the color and position of which indicated what was required.

On the evening of the 20th of June, the floating took place. 'The pontoons, having been rendered buoyant by the closing of the valves, rose with the tide until they reached the bottom of the tube, which was lifted clear off the temporary piers at half-past seven. 'The land attachments being cast off, and the capstans of the hauling-out lines set in motion, the mass swung out into the stream at a rapid pace. When the proper distance from shore had been reached, a chain, made fast to the back of the tube, was cast off, and the onward progress began. By means of the cable-stoppers, which acted admirably, the speed was kept at about $1 ?$ mile per hour. When about three-quarters of the journey had been performed, and the tube had begun to take a position close to the Britannia Rock, and oblique to the course of the tide, a delay arose, owing to an accident at the "Llanfair Capstan," on the Anglesey shore, where the coils of the rope over-rode one another, and prevented the motion of the capstan; as the tube, therefore, floated on, it dragged the capstan from its fraine; and, but for the superintendent of the capstan inducing the crowd of lookers-on to take hold of the long end of the rope, and by the weight of hundreds prevent its further slipping, there is much cause to fear that the pontoons would have grounded on the Britannia Rock, and the whole have been wrecked.

The key to the concluding steps of the floating was a pile of timber and stonework, beyond, but close to, the Anglesey land-tower, called the "Anglesey Butt:" against this, as a pivot, the tube was to bear while being veered across the opening, at right angles to the line of the current. Cp to this it was hauled by a powerful crab behind the Butt; after which, the delicate operations necessary for inserting the high end into the recess in the Britannia Tower (only two inches wider than the tube in its oblique position) were performed by the two capstans and the large crab on the Britannia Rock. The tube having been hauled home at the Britannia Tower, it only remained to bring it into the open recess in the land tower, which was done at twenty-two minutes after nine, when the welcome "All right!" of Mr. Stephenson was the signal for loud and prolonged cheering and firing of cannon. As the tide ebbed, the pontoon. floated away from below, leaving the tube to span the opening with no real or imaginary assistance.

The tube having reached its destination at the foot of the piers, the next operation was to lift it through the 100 feet between that position and its ultimate place. 'This was done by hydraulic presses of enormous dimensions; that at the Anglesey end having a ram of 20 inches diameter, and a cylinder 10 inches thick; and that at the Britannia end, two cylinders, with rams 18 inches diameter. The ram carried a cross-head of prodigious strength, of cast iron, strengthened on the top side by wrought iron links, put on hot; from it depended the lifting-chains, the lower ends of which were secured to the beams in the end of the tube. "The "strolie" 
of the press, or the height of which it was capable of lifting through, was six feet, and each link of the lifting-chains corresponded in length. 'These were formed like those of a suspension bridge, alternately of eight or nine bars. On the upper part of the frame of the press, 12 feet below the top of the cross-head when at the highest point of its lift, was an arrangement of "clams," which were blocks of iron, planed accurately to fit the square shoulders of the head of the chain: by screws and gearing these clams could be opened or closed, so as to let the chain pass, or to embrace and hold it firmly. On the cross-head was a precisely similar arrangement. When, therefore, the press had completed its lift of six feet, the head of the third link had just reached the level of the clams. These being brought in under the shoulders of the link, transferred to themselves the weight of the dependent tube. 'The clams on the cross-heads were then opened, the ram lowered, the top link taken off, the cross-head clams closed, and the bottom clams opened, when all was ready for another lift of six feet.

'The whole of this pondercus machinery was supported on beams of wrought-iron, of immense strength, which spanned the tower above the tube.

'The time occupied in making each lift of six feet was about $38 \mathrm{mi}-$ nutes. The precaution was taken to underbuild the tube with brickwork in cement, filling up the recess in the towers. During the lift, a packing of thin wood was introduced between the top of the brickwork and the bottom of the tube, that, in case of accident, an inch might be the greatest distance fallen through. That these precautions were not needless, was shown on the 17th of August, when the bottom of the cylinder of the single press broke, and allowed the tube to descend on to the packing. No serious injury was done to the tube, though the delay in procuring a new cylinder was considerable. By the 13 th of October the full height was reached.

'The expansion and contraction of such a length of metal is considerable, even under ordinary changes of temperature. Its effects are rendered more manageable by allowing the tube to rest in the Britannia Tower, and to expand outwards in both directions; there being arrangements of rollers, \&c., in the land-tower abutments, to facilitate its motion. The greatest motion hitherto observed in each half is $3_{1}^{3}$ inches. By a simple arrangement of clockwork moving a ruled paper (the tube itself carrying a pencil,) a daily register of this motion is kept.

'The second tube was floated on the 4th of December, and lifted to its plare on the 7th of January, 1850. The last of the land tubes for the first line was lowered to its place on the 4th of March, and on the 5th, Mr. Stephenson and staff passed through with a monstrous train, drawn by three locomotives.

Ten days after this, the line was tested by the Government Inspector, with a train 434 feet long; which caused a deflexion of not $\frac{3}{4}$ inch.

The third tube was floated on the 10th of June, and deposited on its permanent bed on the ilth of July. The fourth tube was floated on the 25 th of the same month, and placed on the 12th of September.

The total weight of the tubes is nearly 11,000 tons. 'This weight is made up of 9360 tons of wrought-iron, and more than 1200 tons of cast- 
iron and timber. They are copposed of about 186,000 separate pieces of iron, pierced by more than 7,000,000 of holes, and united by upwards of 2,000,000 rivets, the angle and 'T-iron being not less than 83 miles in length. 'The weight of the lifting chains alone, at each end of the tube, was more than 40 tons, which, with the cross-head and ram of the press, made a total of more than 60 tons to be lifted before any effect could be produced on the tube itself. Of the masonry in the towers and abutments, there was about 2,500,000 of cubic feet; the weight in all being about 150,000 tons. Allowing twelve working hours in the day, and six to the week, this masonry was prepared and laid at the rate of three cubic feet per minute during the whole time of construction.

The resident engineers, to whose charge the execution of the masonry and ironwork was confided, were, respectively, Mr. Frank Foster, and Mr. Edwin Clark. The designs for the masonry, were by Mr. Francis Thompson.

One of the tubes was constructed by Messrs. Farforth, and the remainder by Mr. Charles Mare. The hydraulic presses and lifting arrangements were elaborated by Messirs. Easton and Amos; and the contractors for the masonry were Messrs. Nowell, Hemmingway, and Pearson.

\section{Cornish Engines.*}

The number of pumping engines reported this month is 26 . They have consumed 2,854 tons of coal; and lifted 26,000,000 tons of water 10 fathoms high. The average duty of the whole is therefore 51,000 ,$000 \mathrm{lbs}$. lifted one foot high by the consumption of $94 \mathrm{lbs}$. of coal.(Lean's Engine Reporter, 12th February.)

\section{Railways of the World. $\dagger$}

It is stated in a work recently published, that there were in operation at the. commencement of 1849 , in different parts of the globe, a total length of 18,656 miles of railway, on which a capital of $£ 368,567,000$ bad been actually expended. In progress of construction, a further extent of 7829 miles, the cost of which, when completed, would be $£ 146,750,000$.

A Description of the Royal Border Bridge, erecled over the River Twoed, on the line of the York, Newcastle, and Berwick Railway. By Mr. G. B. Bruce, $\boldsymbol{M}$. Inst. C. $\boldsymbol{E} . \mp$

This viaduct, the total length of which was 2160 feet, and the extreme height 129 feet, consisted of 28 semi-circular arches, each 61 feet 6 inches span; and the whole constructed of stone, with the exception of the inner part of the arches, which was of brick laid in cement. It was divided

* From the London Railway Journal, No. 611. † Ibid 606.

$\ddagger$ From the London Mining Journal, No. 810. 